\title{
Experimental Study on Permeability Stress Sensitivity in Tight Sandstone Oil Reservoirs
}

(Kajian Eksperimen ke atas Kepekaan Tegasan Ketelapan dalam Reservoir Minyak Batu Pasir Padat)

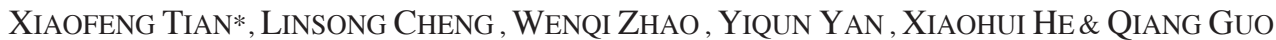

\begin{abstract}
In this paper, seven permeability stress sensitivity experiments were conducted to show the features of permeability stress sensitivity. The cores in the experiments were taken from the tight sandstone oil reservoir in Ordos Basin. Then advanced technologies, such as casting thin section, scanning electron microscope and rate-controlled mercury penetration, were applied to explain the mechanism of permeability stress sensitivity in tight oil reservoirs. The results indicated that the permeability reduction and recovery in gas permeability stress sensitivity increases as the permeability decreases. This was resulted from the maximal throat radius. The permeability reduction in liquid permeability stress sensitivity increases at first and then decreases as the permeability decreases. The permeability recovery decreases to zero as the permeability decreases. Additionally, the differences between gas and liquid permeability stress sensitivity become greater as the permeability decreases. These were resulted from the effect of the critical throat radius. This paper corrects the mistakes about the stress sensitivity in tight oil reservoirs from gas permeability stress sensitivity experiments which is significant to the development of tight sandstone oil reservoirs.
\end{abstract}

Keywords: Critical throat; permeability stress sensitivity; throat distribution; tight sandstone oil reservoir

\section{ABSTRAK}

Dalam kertas ini, tujuh uji kaji kadar resapan tekanan kepekaan telah dijalankan untuk menunjukkan ciri kepekaan tegasan ketelapan. Teras dalam uji kaji ini telah diambil dari reservoir minyak batu pasir padat di Lembangan Ordos. Selepas itu, teknologi yang lebih maju seperti pemilihan irisan nipis, mikroskop elektron imbasan dan penembusan merkuri tahap-dikawal digunakan untuk menerangkan mekanisme kepekaan tegasan ketelapan dalam reservoir minyak yang padat. Keputusan menunjukkan pengurangan ketelapan dan perolehan dalam gas kepekaan tegasan ketelapan meningkat apabila ketelapan berkurangan. Ini adalah akibat daripada jejari keluk maksimum. Pengurangan ketelapan dalam cecair kepekaan tegasan ketelapan pada mulanya meningkat dan kemudian penurunan apabila ketelapan berkurangan. Ketelapan perolehan menurun kepada sifar apabila ketelapan menurun. Di samping itu, perbezaan antara gas dan cecair kepekaan tegasan ketelapan menjadi lebih besar apabila ketelapan menurun. Ini disebabkan kesan daripada jejari keluk yang kritikal. Kertas ini membetulkan kesilapan tentang kepekaan tegasan dalam reservoir minyak yang padat daripada eksperimen kepekaan tegasan ketelapan gas yang penting kepada pembangunan reservoir minyak batu pasir yang padat.

Kata kunci: Keluk kritikal; kepekaan tegasan ketelapan; pengagihan keluk; reservoir minyak batu pasir padat

\section{INTRODUCTION}

Stress sensitivity of petroleum reservoir is that the petrophysical parameters change when the effective stress acting on it changes. Permeability stress sensitivity affects petroleum development significantly. The development of stress sensitivity research has experienced the following stages.

Terzaghi (1943) studied the flow behavior in the saturated deformable medium and came up with the concept of effective stress in (1) which is the foundations of the stress sensitivity.

$$
\sigma_{e f f}=\sigma-p
$$

where $\sigma_{\text {eff }}$ is the effective stress sensitivity; MPa $\sigma$ is overlying pressure; MPa $p$ is the formation pressure, MPa.
Latchie et al. (1958) conducted the stress sensitivity experiments with the cores whose permeability ranged from 3 to $102 \mathrm{mD}$ and studied the relation of $K_{\mathrm{i}} / K_{\mathrm{o}}$ vs $\sigma_{\text {eff }}$ The fluid in the experiments is oil. It was found that the irreversible reduction for permeability was $4 \%$ in the high permeability cores while that reached up to $60 \%$ in the low permeability cores. This indicates that elastic and plastic strain both exit.

Fatt (1958) conducted the stress sensitivity experiments of porosity and permeability with the cores whose permeability ranged from 3 to $630 \mathrm{mD}$. The fluid in the experiments is gas. When the confining pressure was 34 $\mathrm{MPa}$, the porosity and permeability reduction were 5 and $25 \%$, respectively. According to the experiment's results, he concluded that the porosity stress sensitivity could be neglected while that of permeability could not in site. 
Jones (1988) conducted gas stress sensitivity experiments with the two-point method to study the relation of permeability and porosity vs net confining stress. The cores' permeability in the experiments ranged from 10 to $700 \mathrm{mD}$.

Jose (1997) found the gas permeability reduction increase to $90 \%$ in the tight gas reservoir when the cores were compressed.

Ruilan et al. (2007) conducted gas permeability stress sensitivity experiments to evaluate the stress sensitivity of tight gas reservoirs. The cores' Klinkenberg permeability in the experiments ranged from 0.1 to $3 \mathrm{mD}$. She came up with a new coefficient (2) to describe the permeability reduction in permeability stress sensitivity.

$$
s_{p}=\frac{\lg \frac{K_{\min }}{K_{o}}}{\lg \frac{\sigma_{\max }}{\sigma_{o}}},
$$

where $s_{\mathrm{p}}$ is the stress sensitivity coefficient; $K_{\min }$ is the permeability when the effective stress is $\sigma_{\max }, \mathrm{mD} ; K_{\mathrm{o}}$ is the permeability when the effective stress is $\sigma_{o}, \mathrm{mD} ; \sigma_{\max }$ is the maximal effective stress and $\mathrm{MPa} \sigma_{\mathrm{o}}$ is the initial effective stress, $\mathrm{MPa}$.

Junchang et al. (2013) compared the differences of the stress sensitivity features measured by gas, water and oil and explained the differences from the aspect of wettability. Recently, tight oil reservoirs whose permeability is less than $0.1 \mathrm{mD}$ is the hot topic discuss worldwide. However, existing researches focus on the permeability stress sensitivity in low-permeability reservoirs and conventional reservoirs. Permeability of low-permeability reservoirs and conventional reservoirs is larger than $0.1 \mathrm{mD}$. In addition, existing studies focus on the permeability's effect on the features of permeability stress sensitivity. However, the differences of micro pore-throat features in tight oil reservoirs with the same permeability are great. This leads to its effect on permeability stress sensitivity which is great. However, no existing studies are focusing on it. As a result, the features and mechanism of permeability stress sensitivity in tight oil reservoirs are still unknown. This will result in a rapid production reduction. In this paper, seven permeability stress sensitivity experiments were conducted to show and compare the features of permeability stress sensitivity measured by different fluids. The cores in the experiments were taken from the tight oil reservoir in Ordos Basin. Then advanced technologies, such as casting thin section, scanning electron microscope and rate-controlled mercury penetration, were applied to explain the mechanism of permeability stress sensitivity in tight oil reservoirs.

\section{MATERIALS}

Fatt and Davis (1952) and Fatt (1958) found that the permeability stress sensitivity is far more serious than that of porosity. Therefore, this paper focuses on permeability stress sensitivity. The cores used in the experiments were taken from the Member 7 tight oil reservoir, Yanchang Formation, Ordos Basin. The basic parameters are shown in Table 1. It is known from Table 1 that the permeability of the cores from the tight oil reservoir is ultra low.

Table 2 is the basic parameters of the Member 7 tight oil reservoir, Yanchang Formation, Ordos Basin. From Table 2, it is known that the average density of the rock is

TABLE 1. Basic parameters of the cores

\begin{tabular}{cccccc}
\hline $\begin{array}{c}\text { Number of } \\
\text { cores }\end{array}$ & $\begin{array}{c}\text { Length } \\
(\mathrm{cm})\end{array}$ & $\begin{array}{c}\text { Diameter } \\
(\mathrm{mm})\end{array}$ & $\begin{array}{c}\text { Porosity } \\
(\%)\end{array}$ & $\begin{array}{c}\text { Gas permeability } \\
(\mathrm{mD})\end{array}$ & $\begin{array}{c}\text { Fluid used in } \\
\text { experiments }\end{array}$ \\
\hline 1 & 6.1 & 25.1 & 11.7 & 0.35 & Nitrogen \\
2 & 6.4 & 25.0 & 10.6 & 0.11 & \\
3 & 6.0 & 25.1 & 9.3 & 0.0085 & Kerosene \\
4 & 5.8 & 25.2 & 10.1 & 0.084 & \\
5 & 6.2 & 24.9 & 9.7 & 0.039 & 0.019 \\
6 & 5.2 & 25.1 & 9.6 & 0.0085 & \\
7 & 5.5 & 25.0 & 9.2 & & \\
\hline
\end{tabular}

TABLE 2. Basic parameters of the tight oil reservoir

\begin{tabular}{lccc}
\hline Well & Layer & Depth $(\mathrm{m})$ & Rock density $\left(\mathrm{g} / \mathrm{cm}^{3}\right)$ \\
\hline N68 & Member 7 & 1773.83 & 2.39 \\
N68 & Member 7 & 1775.65 & 2.41 \\
L94 & Member 7 & 1780.64 & 2.36 \\
Z11 & Member 7 & 1792.34 & 2.37 \\
X62 & Member 7 & 1802.69 & 2.37 \\
Z30 & Member 7 & 1824.26 & 2.36 \\
Z49 & Member 7 & 1815.85 & 2.39 \\
Z49 & Member 7 & 1850.9 & 2.33 \\
\hline
\end{tabular}


$2.37 \mathrm{~g} / \mathrm{cm}^{3}$ and the average depth of the reservoir is 1800 $\mathrm{m}$ that of the formation liquid is $1 \mathrm{~g} / \mathrm{cm}^{3}$. Baohong et al. (2012) found that the average formation fluid density is $1 \mathrm{~g} /$ $\mathrm{cm}^{3}$. According to equation (3), the overlying rock pressure is calculated to be $42 \mathrm{MPa}$ and the formation pressure is 18 $\mathrm{MPa}$, with $24 \mathrm{MPa}$ initial effective stresses. An ISCO pump imported from America was used to provide pressure. The fluids used in the experiments were nitrogen and kerosene, respectively. This is because kerosene could avoid the permeability reduction resulted from water sensitivity. The lather flow meter and the metering capillary tube were used to measure the flow rate of nitrogen and kerosene.

$$
p=\rho g h,
$$

where $p$ is pressure, $10^{-3} \mathrm{MPa} ; \rho$ is density, $\mathrm{g} / \mathrm{cm}^{3} ; g$ is gravitational acceleration, $\mathrm{m} / \mathrm{s}^{2}$; and $h$ is depth, $\mathrm{m}$.

\section{METHODS}

\section{GAS PERMEABILITY STRESS SENSITIVITY EXPERIMENTS}

Because the initial formation pressure (18 MPa) exceeds the maximal pressure of the pressure reducing valve on the nitrogen cylinder, the displacement pressure had to stay constant and the confining pressure changed to adjust the effective stress. Because advanced water injection technology is widely applied in the tight oil reservoirs. This leads to a higher formation pressure and a lower effective stress. Therefore, the confining pressure was finally determined to be $18 \mathrm{MPa}$. The displacement pressure was $4 \mathrm{MPa}$ and the back pressure was $2 \mathrm{MPa}$. The formation pressure is the average value of displacement pressure and back pressure, $3 \mathrm{MPa}$. The effective stress equals the confining pressure minus formation pressure, $15 \mathrm{MPa}$. Then the confining pressure was adjusted to 23, 28, 33, 38, $33,28,23,18 \mathrm{MPa}$ successively. The experimental facility can be seen in Figure 1. The stabilization time was $30 \mathrm{~min}$.

\section{LIQUID PERMEABILITY STRESS SENSITIVITY EXPERIMENTS}

In order to simulate the development of the tight oil reservoir, the confining pressure had to stay constant and formation pressure changed to adjust the effective stress.
This is because the confining pressure simulates overlying rock pressure. It is the same with gas permeability stress sensitivity experiments. The confining pressure, the displacement pressure and the back pressure were 40, 30 and $20 \mathrm{MPa}$, respectively. The initial formation pressure was $25 \mathrm{MPa}$ and the initial effective stress was $15 \mathrm{MPa}$. Then the displacement pressure changed to $25,20,15$, $10,15,20,25,30 \mathrm{MPa}$ and the back pressure changed to $15,10,5,0,5,10,15,20 \mathrm{MPa}$. The experimental facility can be seen in Figure 1. The stabilization time was $24 \mathrm{~h}$.

\section{RESULTS AND DISCUSSION}

The permeability reduction $\left(R_{e d}\right)$ and recovery $\left(R_{e c}\right)$ are the evaluation indexes of permeability stress sensitivity.

$$
\begin{aligned}
& R_{e d}=1-K_{r \min } . \\
& R_{e c}=K^{\prime}-K_{r \min },
\end{aligned}
$$

where $R_{e d}$ is the permeability reduction; 1 is the original relative permeability, because the denominator of relative permeability is original permeability, when the effective stress is the original, the original relative permeability is 1 ; $K_{\text {rmin }}$ is the relative permeability when the effective stress is the maximum; $R_{e c}$ is the permeability recovery; and $K$ ' is the relative permeability when effective stress decreases to the minimum.

\section{GAS PERMEABILITY STRESS SENSITIVITY EXPERIMENTS}

Figure 2 shows the gas permeability stress sensitivity (GSS) experimental results. It was found that as permeability becomes lower, $R_{e d}$ and $R_{e c}$ both becomes larger.

Permeability is the reflection of throats, so the strain of throats is the nature of stress sensitivity. The diameter of nitrogen molecules is $0.304 \mathrm{~nm}$. It is so small that all throats can be fit in. Therefore, GSS can reflect the strain of all throats. Because GSS is a single phase flow behavior, capillary pressure is neglected. Permeability is derived (8) according to Darcy Equation (6) and Poiseuille Equation (7).

$$
Q=\frac{K \cdot A}{\mu} \nabla p .
$$

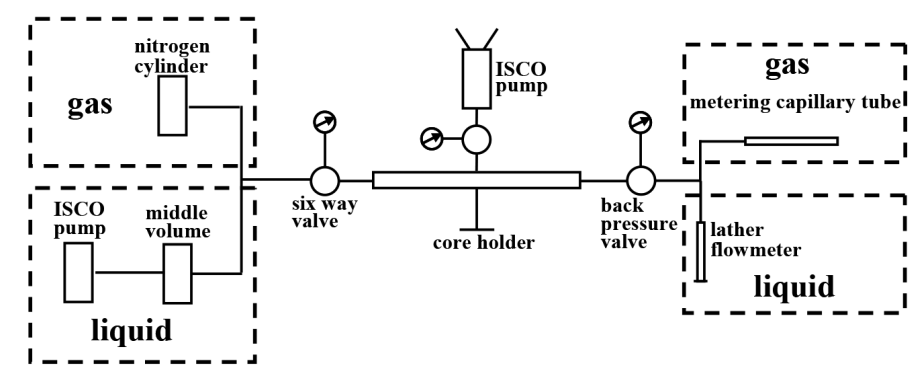

FIGURE 1. Schematic of stress sensitivity experimental facility 


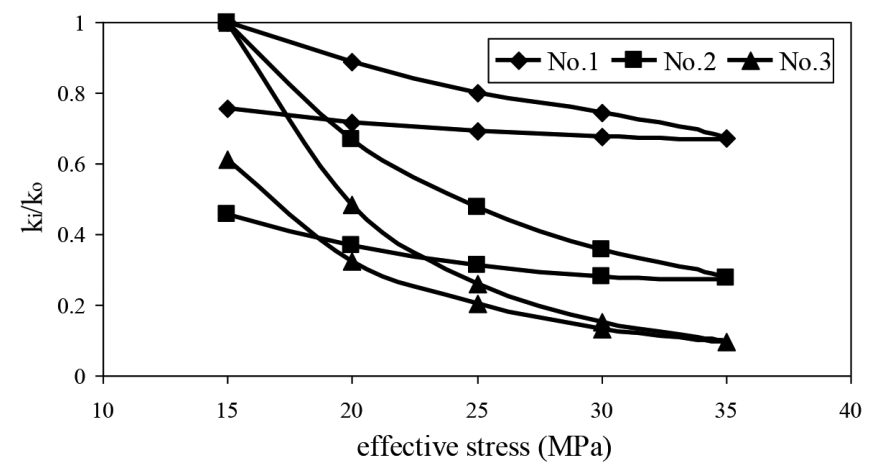

FIGURE 2. Gas-measured stress sensitivity experimental results

$$
\begin{aligned}
& Q=\sum_{r_{\min }}^{r_{\max }} \frac{n_{i} \cdot \pi r_{i}^{4}}{8 \mu} \nabla p . \\
& K=\sum_{r_{\min }}^{r_{\max }} \frac{n_{i} \cdot \pi r_{i}^{4}}{8 A},
\end{aligned}
$$

where $Q$ is flow rate of core, $10^{-6} \mathrm{~m}^{3} / \mathrm{s} ; K$ is permeability, $\mathrm{mD} ; A$ is sectional area, $\mathrm{m}^{2} ; \nabla p$ is the pressure gradient, $\mathrm{MPa} / \mathrm{m} ; \mu$ is the viscosity, $\mathrm{mPa} . \mathrm{s} ; r_{\max }$ is the maximal throat radius, $\mu \mathrm{m} ; r_{\min }$ is the minimal throat radius, $\mu \mathrm{m}$; and $r_{i}$ is the throat radius, $\mu \mathrm{m}$.

When the throat is acted by effective stress, it is assumed that the compressive degree is $c$. Then permeability when acted by effective stress is obtained by substituting $c$ into (7).

$$
K^{\prime}=\sum_{r_{\min }}^{r_{\max }} \frac{n_{\mathrm{i}} \cdot \pi\left[r_{\mathrm{i}}\left(1-c_{i}\right)\right]^{4}}{8 A}
$$

where $K^{\prime}$ is permeability of core when acted by the effective stress, $\mathrm{mD} ; c_{\mathrm{i}}$ is compressive degree of throat whose radius is $r_{\mathrm{i}}$, dimensionless.

According to (7) and (8), $R_{e d}$ is derived (9).

$$
R_{e d}=\frac{\sum_{r_{\min }}^{r_{\max }}\left\{\left[1-\left(1-c_{i}\right)^{4}\right] n_{i} r_{i}^{4}\right\}}{\sum_{r_{\min }}^{r_{\max }} n_{i} r_{i}^{4}}
$$

where $n_{i} r_{i}^{4} / \sum_{r_{\min }}^{r_{\max }} n_{i} r_{i}^{4}$ is permeability contribution of throats whose radius is $r_{\mathrm{i}}$, dimensionless.

From (9) it is known that the contribution to permeability and compressive degree affects $R_{e d}$ significantly. The function of second cement of ferrocalcite and secondary enlargement of quartz reduces the throat radius (Figure $3)$. But due to the support of ferrocalcite and quartz, the absolute strain of tinier throats is smaller than that of larger throats with the same effective stress. However, the relative strain of tinier throats is larger. Therefore, larger throats are easier to be compressed when acted by the effective stress and they contribute more to permeability. That is the reason that permeability decreases fast at first and then becomes slow. As permeability decreases, the permeability contribution and relative strain of tinier throats becomes larger (Figure 4$)$. Therefore, $R_{e d}$ is larger when the permeability is lower.

Because the rock compositions of tiny throats and large ones are the same, they have the same elastic limits. As the absolute strain of the larger throats is larger, they reach the elastic limit first and generate plastic strain. Therefore, when the effective stress decreases, the tinier throats have the larger recovery. Figure 4 is the results of three ratecontrolled mercury penetration experiments. From Figure 4 it is found that the permeability contribution of tinier throats increases as the permeability decreases. Therefore, the permeability recovery increases as permeability decreases.

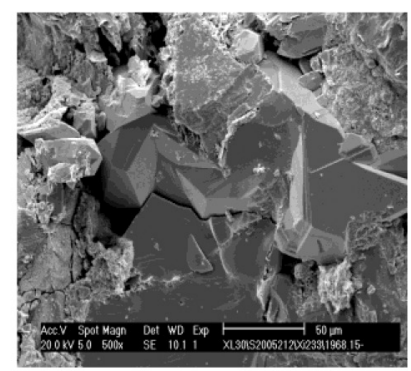

(b) the secondary enlargement of quartz

(a) the cement of ferrocalcite

FIGURE 3. Diagenesis in the tight oil reservoir 


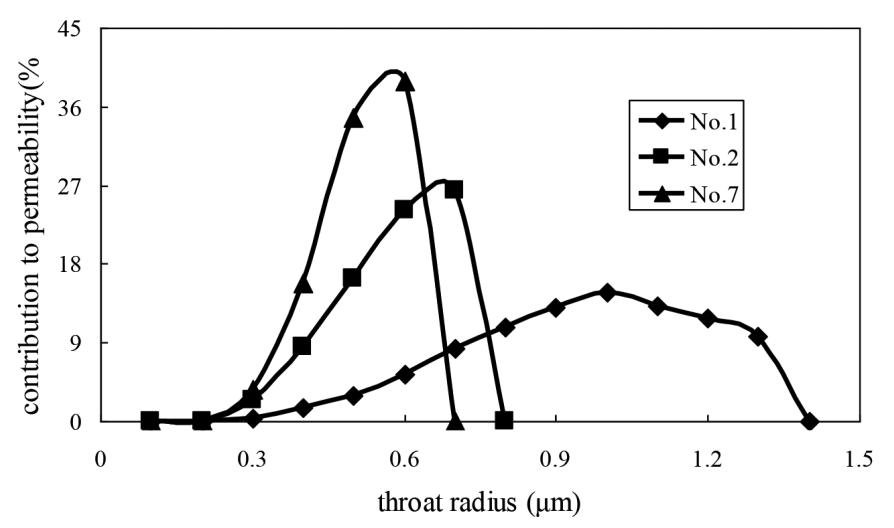

FIGURE 4. Distribution of throat contribution to permeability

\section{LIQUID PERMEABILITY STRESS SENSITIVITY EXPERIMENTS}

Figure 5 shows the liquid permeability experimental results. The results of No. 4 and No. 5 indicate that as permeability decreases, the liquid permeability reduction increases. Additionally, the results of No. 5 to No. 7 indicate that as permeability decreases, the liquid permeability reduction reduces. When the effective stress decreases, permeability does not recover.

The permeability of the four cores in the Figure 5 is extremely low (less than $0.1 \mathrm{mD}$ ). These cores are the typical tight oil reservoir cores. Caineng et al. (2011) came up with the concept that there was a critical throat radius in tight oil reservoirs. Due to the effect of the critical radius $\left(r_{c}\right)$, the features of the stress sensitivity measured by gas and liquid are different.

Because the liquid permeability stress sensitivity experiments are single phase flow, the capillary pressure is neglected. By modifying the expression of gas permeability reduction (9), the liquid permeability reduction is obtained (10). Compared to gas permeability reduction, liquid permeability reduction takes boundary layer and critical throat into account.

$$
R_{e d}=\frac{\sum_{r_{c}}^{r_{c}^{\prime}} n_{i} r_{i}^{4}\left(1-\frac{h_{i}}{r_{i}}\right)^{4}}{\sum_{r_{c}}^{r_{\max }} n_{i} r_{i}^{4}\left(1-\frac{h_{i}}{r_{i}}\right)^{4}}+\frac{\sum_{r_{c}^{\prime}}^{r_{\max }} n_{i} r_{i}^{4}\left[\left(1-\frac{h_{i}}{r_{i}}\right)^{4}-\left(1-c_{i}\right)^{4}\left(1-\frac{h_{i}^{\prime}}{r_{i}^{\prime}}\right)^{4}\right]}{\sum_{r_{c}}^{r_{\max }} n_{i} r_{i}^{4}\left(1-\frac{h_{i}}{r_{i}}\right)^{4}},
$$

where $r_{c}$ is the critical throat radius, $\mu \mathrm{m} ; h_{i}$ is the boundary layer thickness in the throat whose radius is $r_{\mathrm{i}}, \mu \mathrm{m}$; $r_{\mathrm{i}}{ }^{\prime}$ is the throat radius when acted by effective stress whose radius is $r_{i}, \mu \mathrm{m} ; r_{c}$ ' is the throat radius which is becoming to be $r_{\mathrm{c}}$ when acted by effective stress, $\mu \mathrm{m}$; and $h_{\mathrm{i}}$ ' is the boundary layer thickness in the throat whose radius is $r_{\mathrm{i}}{ }^{\prime}, \mu \mathrm{m}$;

From (10), it is known that the permeability reduction consists of two parts. The first item of the (10) is permeability contributed by throats whose radius ranges from $r_{\mathrm{c}}$ to $r_{\mathrm{c}}$ '. When acted by the effective stress, the permeability of these throats loss completely. The second item of (10) is the permeability contributed by throats whose radius is larger than $r_{c}$. When permeability is high, the permeability contribution of throats whose radius ranges from $r_{\mathrm{c}}$ to $r_{\mathrm{c}}$ ' is tiny. Therefore, the effect of the first item can be neglected. That is the reason that from No. 4 to No. 5 the permeability reduction increases. As permeability decreases, the effect of the second item decreases and that of the first item increases. The peak of the throat distribution moves from the right side of the critical throat radius to the left side. In this case, the first item affects liquid permeability reduction significantly. As permeability decreases, the proportion of throats whose radius ranges from $r_{\mathrm{c}}$ to $r_{\mathrm{c}}$ ' decreases rapidly. As a result, from No. 5 to No. 7, the liquid permeability reduction decreases.

The plastic strain of larger throats is more serious than that of tinier throats. Therefore, as the effective stress

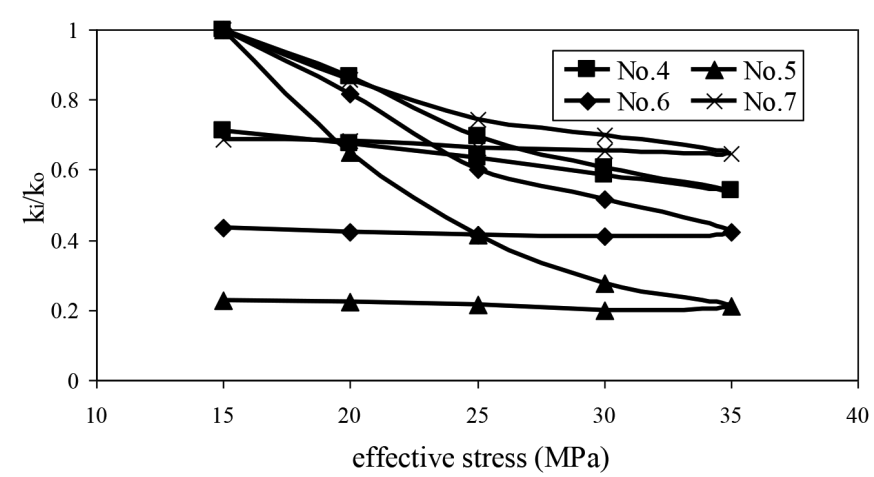

FIGURE 5. Liquid-measured stress sensitivity experimental results 


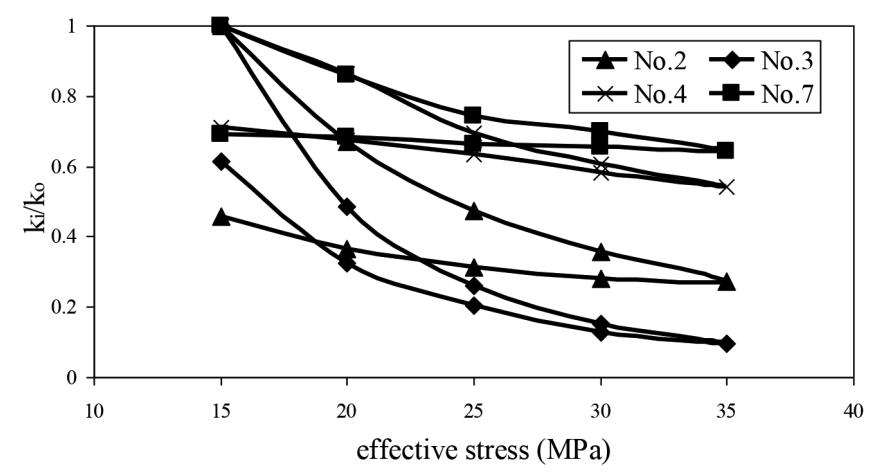

FIGURE 6. Comparison of gas and liquid stress sensitivity

decreases, the elastic recovery mostly happens in tinier throats. However, the radius of tinier throats is smaller than $r_{c}$ and the elastic recovery has no contribution to liquid permeability. As a result, the liquid permeability does not recover. When the permeability is high, the range of the throats distribution is wide. The elastic recovery appears in the throats whose radius is larger than $r_{\mathrm{c}}$. Therefore, the liquid permeability recovers when permeability is high. In conclusion, as the permeability decreases, the liquid permeability recovery increases first and then decreases to 0 .

\section{COMPARISON OF STRESS SENSITIVITY MEASURED BY GAS AND LIQUID}

Figure 6 compares the results of permeability stress sensitivity measured by gas and liquid. The cores in the gas permeability stress sensitivity experiments have the approximate permeability with the cores in the liquid permeability stress sensitivity experiments. From Figure 6 , it is found that the reduction and recovery of gas permeability are both larger than that for liquid permeability. Moreover, as permeability decreases, the differences increase.

Due to the effect of $r_{\mathrm{c}}$, the tinier throats have no contribution to liquid permeability. However, their relative strain and elastic recovery are both larger. It is the reason that the reduction and recovery of gas permeability are larger than that of liquid permeability. As permeability decreases and the range of the throat distribution shrinks, the proportion of throats whose radius is smaller than $r_{\mathrm{c}}$ becomes larger. Therefore, the differences between gas and liquid permeability stress sensitivity become larger.

\section{CONCLUSION}

The permeability reduction and recovery of gas permeability stress sensitivity increases as the permeability decreases. The maximal throat radius affects gas permeability reduction and recovery most. The permeability reduction in liquid permeability stress sensitivity increases at first and then decreases as the permeability decreases. The liquid permeability recovery decreases to zero as the permeability decreases. The critical throat radius affects gas permeability reduction and recovery most. As the permeability decreases, the differences between gas and liquid permeability stress sensitivity become bigger. The critical throat radius affects the differences of permeability reduction and recovery between gas and liquid most.

\section{ACKNOWLEDGEMENTS}

This work was supported by National Natural Science Foundation of China (51174215/E0403), The PhD. Programs Foundation of Ministry of Education of China (20130007120014) and National Science and Technology Major Project of the Ministry of Science and Technology of China (2011ZX05013-004). The financial support is gratefully acknowledged.

\section{REFERENCES}

Baohong, S., Yan, Z., Lei, Z., Yajuan, Y. \& Hui, L. 2012. Hydrocarbon accumulation dating by fluid inclusion characteristics in Chang7 tight sandstone reservoirs of Yanchang Formation in Ordos Basin. Petroleum Geology \& Experiment 34(6): 599-603.

Caineng, Z., Rukai, Z., Bin, B., Zhi, Y., Songtao, W. \& Ling, S. 2011. First discovery of nano-pore throat in oil and gas reservoir in China and its scientific value. Acta Petrologica Sinica 27(6): 1857-1864.

Fatt, I. \& Davis. D.H. 1952. Reduction in permeability with overburden pressure. Journal of Petroleum Technology 4(12): 16

Fatt, I. 1958. Pore volume compressibilities of sandstone reservoirs rocks. Journal of Petroleum Technology 42(8): 64-66.

Jones, S.C. 1988. Two-point determinations of permeability and PV vs net confining stress. SPE Formation Evaluation 3: 235-241.

Jose, G. 1997. Numerical simulation of coupled fluid-flow/ geomechanical behavior of tight gas reservoirs with stress sensitive permeability. Brazil.Latin American and Caribbean Petroleum Engineering Conference.

Junchang, S., Zhengming, Y. \& Qi, T. 2013. Comparative study on stress-dependent permeability of ultra-low permeability sandstone rock using different types of fluid media. China. International Petroleum Conference.

Latchie, A.S.M., Hemstick, R.A. \& Joung, L.W. 1958. The effective compressibility of reservoir rock and its effect on permeability. Journal of Petroleum Technology 10(6): 49-51. 
Ruilan, L., Linsong, C., Jianchun, P. \& Huayin, Z. 2007. A new method of determining relationship between permeability and effective overburden pressure for low-permeability reservoirs. Journal of China University of Petroleum (Natural Science Edition) 31(2): 87-90.

Terzaghi, K. 1943. Theoretical Soil Mechanics. New Jersey: John Wiley \& Sons Inc. pp. 11-15.

Xiaofeng Tian*, Linsong Cheng, Wenqi Zhao,

Yiqun Yan \& Xiaohui He

Petroleum Engineering Department

China University of Petroleum

102249 Beijing

China
Qiang Guo

Missouri University of Science and Technology 65409 Missouri

United States of America

*Corresponding author; email: txf5160@163.com

Received: 10 December 2013

Accepted: 8 January 2015 